DOI 10.31558/2307-2318.2021.1.3

УДК 336.717

JEL: G21

Волкова В.В.,

кандидат економічних наук, доцент, доцент кафедри фінансів і банківської справи, Донецький національний університет імені Василя Стуса

ORCID ID: 0000-0003-1539-6194

v.volkova@donnu.edu.ua

Волкова Н.І.,

кандидат економічних наук, доцент, доцент кафедри фінансів і банківської справи, Донецький національний університет імені Василя Стуса

ORCID ID: 0000-0003-3790-3636

n.volkova@donnu.edu.ua

Ставська К.А.,

магістрант, Донецький національний університет імені Василя Стуса

ORCID ID: 0000-0002-1010-3236

stavska.k@donnu.edu.ua

\title{
КОНЦЕПЦІЯ ВДОСКОНАЛЕННЯ ОЦНКИ ЯКОСТІ КРЕДИТНОГО ПОРТФЕЛЯ В УПРАВЛІННІ КРЕДИТНОЮ ДІЯЛЬНІСТЮ БАНКУ
}

В статті визначено якість кредитного портфеля як сприятливий стан його структури, при якому банківська установа буде мати можливість забезпечити максимальну дохідність при мінімальному рівні кредитного ризику та оптимальній ліквідності балансу банку. Досліджено динаміку непрацюююих активів та виділено банки з найбільшою їх часткою в кредитному портфелі. Обгрунтовано необхідність більш ефективного управління кредитними ризиками та доиільність оцінки якості кредитного портфреля банку. Розроблено кониепиію вдосконалення оцінки якості кредитного портфеля в управлінні кредитною діяльністю банку, реалізація якої дозволить підвищити ефективність його діяльності та сприятиме розвиткові банківської системи крайни. В статті зроблено акцент на тому, щуо конщепџія вдосконалення оцінки якості кредитного портфеля в управлінні кредитною діяльністю банку - иіілісна система теоретикометодологічних поглядів на сутність, мету, задачі та принципи оцінки якості кредитного портфеля в управлінні кредитною діяльністю банку, а також система організаційнопрактичних підходів до формування механізму ї̈ реалізації в конкретних умовах. Виділено фактори, які впливають на рівень якості кредитного портфеля. Обтрунтування етапів формування кредитної діяльності банку, щзо дозволить банківській установі реалізувати концепцію вдосконалення оцінки якості кредитного портфеля в управлінні кредитною діяльністю банку повною мірою.

Ключові слова: банк, кредитна діяльність, концепція, непрацюючі кредити, управління кредитними ризиками, оцінка якості кредитного портфеля.

Puc. - 5, Таб. -0, Лim. - 9. 
Постановка проблеми. Банківська система виступає невід'ємною частиною економіки будь-якої країни. Вона розвивається, трансформується та адаптується до тієї системи фінансових відносин, що склалася в державі. Кредитна діяльність в Україні протягом останніх декількох років була і лишається на сьогодні самою нестабільною i ризиковою з всіх видів банківських операцій. Саме тому визначення концептуальних засад оцінки кредитного портфеля в управлінні кредитною діяльністю є дуже важливим, що і обумовлює актуальність даної теми.

Аналіз останніх джерел та публікацій. Значний вклад у дослідження даної наукової проблеми внесли вітчизняні та зарубіжні вчені: Довгань Ж.В., [2] Жукова Н.К., [3] Степаненко К.Р. [4] та інші. Однак, незважаючи на значну кількість наукових робіт в цій галузі, багато питань, пов'язаних 3 кредитною діяльністю банків залишаються дискусійними i недостатньо розробленими, що не дозволяє ефективно здійснювати управління цією сферою банківського бізнесу, особливо в умовах нестабільності економіки, що зараз спостерігається у країні.

Мета дослідження полягає у розробці на основі системного підходу концепції вдосконалення оцінки якості кредитного портфеля в управлінні кредитною діяльністю банку, яка сприятиме підвищенню конкурентоспроможності банку на ринку кредитних послуг.

Виклад основного матеріалу дослідження. Банківська система $\epsilon$ необхідним стратегічним сегментом сучасної ринкової економіки будь-якої країни та чинить вплив на економічні та соціальні процеси в країні. Дуже суттєво на економічні процеси в державі впливає діяльність кредитних установ, основу якої складає саме здійснення банківських операцій. Запропонована концепція дасть змогу адаптуватись до викликів сьогодення та досягти цільових орієнтирів його розвитку.

Кредитна діяльність банку - це складний процес щодо пошуку та залучення коштів, дешевших, ніж надання кредиту клієнтам на вихідних умовах, а також управління ризиками, що виникають при супроводжуваному процесу. Головною метою кредитної діяльності будь-якого банку є бажання досягти комерційного зростання завдяки зміцненню та підвищенню надійності якості його кредитного портфеля. Якість кредитного порфеля визначимо як сприятливий стан структури портфеля, при якому банківська установа буде мати можливість забезпечити максимальну дохідність при мінімальному рівні кредитного ризику та оптимальній ліквідності балансу.

Загальний кредитний портфель банків за 2019 рік зменшився на 13\%. Найбільше знизилося кредитування базових та інфраструктурних галузей економіки: добувної $31 \%)$, переробної $(-16 \%)$, будівництво (-18\%), транспорт $(-21 \%)$. Загальна сума виданих кредитів нефінансовим корпораціям за минулий рік зменшилася більше ніж на 115 млрд грн. У 2019 році спостерігалась тенденція поступового скорочення обсягу непрацюючих кредитів у банках України (рис. 1). Рівень непрацюючих кредитів (NPLs) на початок 2020 року у банківському секторі продовжує скорочуватися. Фактори залишаються незмінними зниження обсягів неякісних валютних кредитів унаслідок укріплення гривні; "розмиття" споживчого портфеля новими кредитами та фінансова реструктуризація корпоративних кредитів. Непрацюючі кредити на балансах банків не несуть значного ризику - рівень покриття резервами досяг 93.8\%. Статистика NPLs належно відображає реальну якість портфеля. 


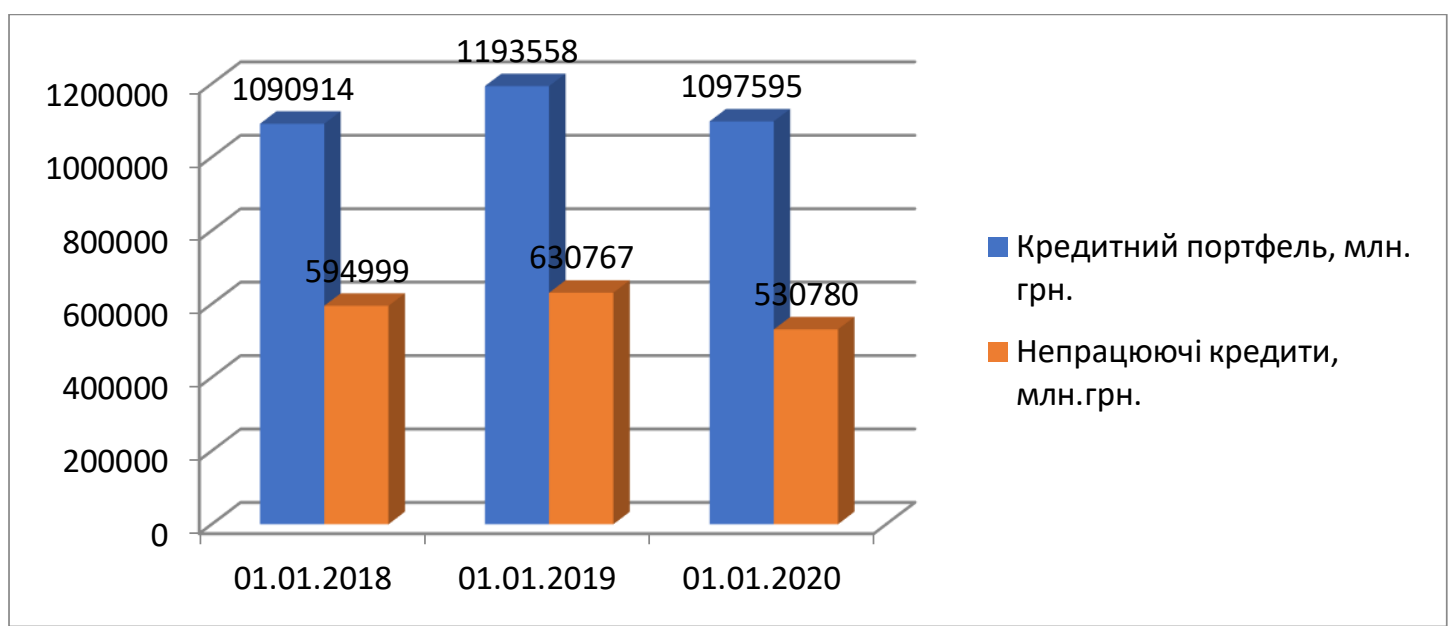

Рисунок 1. Динаміка непрацюючих кредитів в кредитному портфелі банків України за 2018-2020pp.*

*джерело: побудовано авторами за даними Національного банку України [5]

Станом на 01.12.2020 p. майже половину обсягу кредитного портфеля банків складають непрацюючі кредити (42\%, або 449321 млн грн), з яких 58\%, або 320927 млн грн акумульовано у банках державного сектору [5].

При цьому скорочення валового кредитного портфеля банків відбувається переважно за рахунок погашення або списання непрацюючих кредитів. При цьому динаміка видачі нових кредитів, у т.ч. корпоративних, є позитивною, але надто слабкою $і$ непомітною на тлі стагнації кредитного портфеля в цілому. Наразі, очевидно різна динаміка показників ліквідності та кредитування демонструє відсутність пропорційного зв'язку між цими категоріями у реаліях українського ринку.

Дефіцит ліквідності може бути обмежуючим чинником для кредитування. Але в умовах достатньої та навіть надлишкової ліквідності квола динаміка кредитування реального сектору (підприємств і домогосподарств) зумовлена не відсутністю достатньої пропозиції грошей з боку банків, а слабкістю платоспроможного попиту на кредити та високими ризиками. [6].

На рисунку 2 зображено ТОП 10 банків за обсягом непрацюючих кредитів станом на 01.12.2020p.

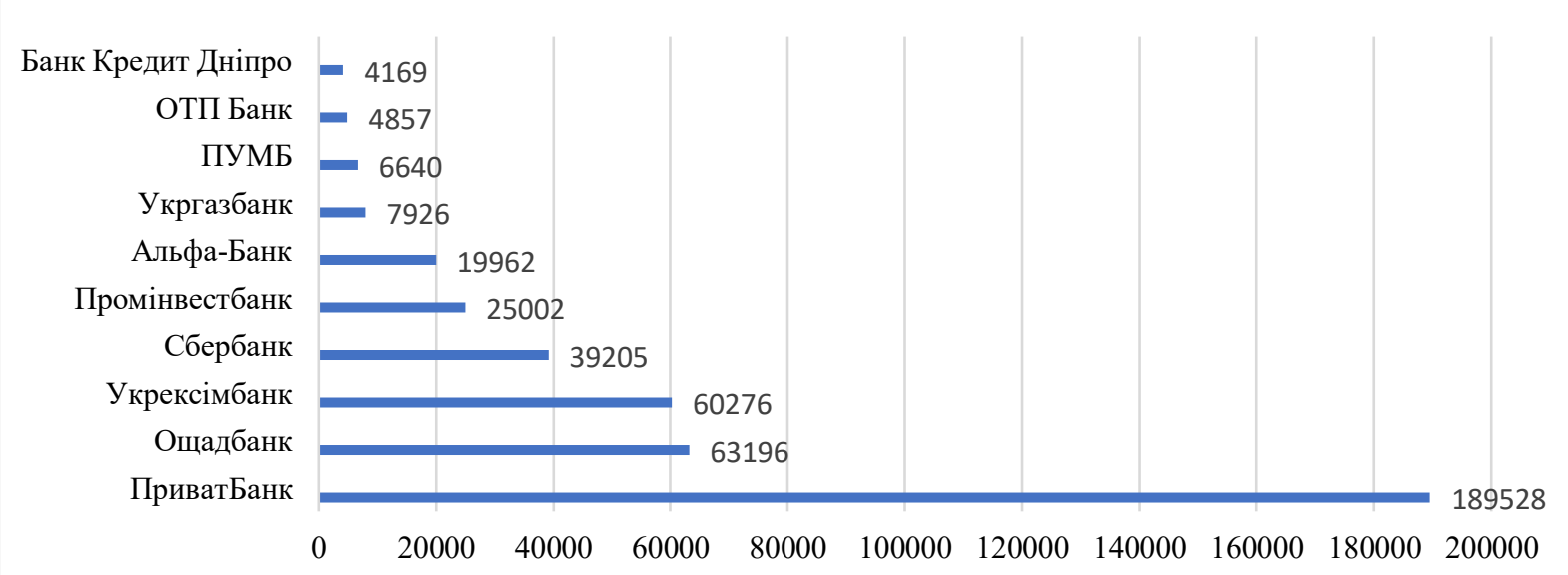

Рисунок 2. ТОП 10 українських банків за обсягом непрацюючих кредитів станом на 01.12.2020p.*

*джерело: побудовано авторами за даними Національного банку України [5] 
B сучасних умовах банківський сектор продовжує долати наслідки пандемії COVID19. У липні - вересні 2020 року основні показники банків відновили зростання. Частка непрацюючих кредитів сягнула мінімального значення з моменту запровадження нового визначення непрацюючих кредитів, що відповідає міжнародним стандартам.

Український банківський сектор залишається високоприбутковим завдяки стійкості операційних прибутків та відсутності значних кредитних втрат.

Водночас у фокусі уваги залишається належна оцінка банками ризиків. Втрати від погіршення якості кредитного портфеля й надалі будуть головним викликом для прибуткової діяльності банків [5].

Справедливо зазначають науковці [1], що для моніторингу ефективності управління кредитним портфелем, банкам необхідно встановити внутрішнє граничне значення коефіцієнта ефективності управління кредитним портфелем, нижче за яке видача кредиту визнаватиметься недоцільною, що дозволить банкам формувати оптимальний з погляду співвідношення доходу та ризику кредитний портфель.

В сучасних умовах політичної та економічної нестабільності підвищується ризикованість банківського кредитування, адже значна кількість наданих позик не повертається своєчасно, зростає питома вага проблемної заборгованості й особливо гострою стає проблема управління якістю кредитного портфеля банку. Більш ефективно управляти кредитними ризиками та формувати адекватні резерви дозволяють комплексний аналіз та адекватна оцінка стану кредитного портфеля. А тому актуальним $є$ дослідження методик оцінки якості кредитного портфеля банку в управлінні кредитною діяльністю.

Оцінка об'єктивного стану позичальника, здатності конкретного позичальника виплатити надану йому позику в конкретний момент часу $є$ фундаментальним критерієм оцінювання кредитного портфеля. Існує також ряд інших факторів, які необхідно приймати до уваги при оцінці кредитного портфеля. Зокрема, це галузева приналежність позичальника, приналежність даного позичальника до компанії, яка асоційована $з$ даним банком, сукупний рівень розвитку економіки, конкурентності, залежність позичальника від постачальників або від державної підтримки. Всі ці фактори в якійсь мірі суб'єктивні, але вони повинні прийматися до уваги при оцінці адекватності кредитного портфеля.

Традиційно для оцінки якості кредитного портфеля використовується запропонована НБУ класифікація кредитної заборгованості на п’ять груп, аналіз дотримання нормативів кредитного ризику та розрахунок різноманітних фінансових коефіцієнтів.

Однак, в сучасних кризових умовах постає питання про якісну інтерпретацію тих чи інших рівнів показників, з'ясування того, яким є отримане значення - малим, середнім чи великим та якою саме мірою малою, середньою або великою, адже часто перехід показника із одного якісного стану до іншого досить важко розмежувати. Тому постає необхідність в розробці концепції вдосконалення оцінки якості кредитного портфеля банків в управлінні кредитною діяльністю (рис. 3).

Концепція - це сукупність взаємопов'язаних елементів, що включає в себе розробку технологій управління кредитною діяльністю банку, так і безпосередньо саму методологію управлінні кредитною діяльністю банку. Концепція вдосконалення оцінки якості кредитного портфеля в управлінні кредитною діяльністю банку - цілісна система теоретико-методологічних поглядів на сутність, мету, задачі та принципи оцінки якості кредитного портфеля в управлінні кредитною діяльністю банку, а також система організаційно-практичних підходів до формування механізму іiі реалізації в конкретних умовах.

Дана концепція представляє собою систему взаємопов'язаних елементів, які включають принципи, мету, задачі та механізми, націлені на модернізацію оцінки 
кредитного портфеля в управлінні кредитною діяльністю як на макро-, так і на мікрорівні, а також на досягнення економічного ефекту, який полягає в поліпшенні якості кредитів та покращенні фінансових результатів банків.

В основі концепції лежать такі принципи:

- системний підхід - комплексне вивчення всіх особливостей оцінки кредитного портфеля банку $з$ метою виявлення недоліків і розробки механізмів їх ефективного розвитку;

- збалансованість - характеризується як досягнення створення необхідних резервів для покриття кредитних ризиків;

- фінансова адекватність - визначає діяльність банку в межах реально наявних ресурсів;

- рівновага - означає взаємозв'язок регулювальних заходів як з боку центрального банку (зовнішнє регулювання), так і банків (внутрішнє регулювання або саморегулювання). Цей принцип тісно пов'язаний з принципом збалансованості;

- комплексність - вимагає обхвату всіх ланок і сторін діяльності, усестороннього вивчення причинно-наслідкових зв'язків в діяльності банку.

Метою даної концепції $є$ вдосконалення оцінки якості його кредитного портфеля задля підвищення ефективності кредитної діяльності банку та отримання максимального прибутку з найменшими витратами.

Відповідно до мети, задачами є:

1) аналіз сучасного стану кредитної діяльності банків України;

2) застосування заходів щодо зниження кредитного ризику;

3) удосконалення нормативно-правової бази у банківській галузі;

4) оптимізація кредитного портфеля.

До засобів досягнення мети належать: використання набору показників оцінки якості кредитного портфеля в управлінні кредитною діяльністю банку; використання методів оцінки якості кредитного портфеля в управлінні кредитною діяльністю банку; виділення шляхів підвищення оцінки якості кредитного портфеля в управлінні кредитною діяльністю банку; розробка моделі оцінки якості кредитного портфеля в управлінні кредитною діяльністю банку.

Вважаємо, що щляхів підвищення якості кредитного портфеля можуть бути:

вдосконалення організації кредитного процесу в банку;

розвиток методів зниження кредитного ризику;

активна участь держави в стимулюванні комерційних банків до посилення цілеспрямованого впливу кредитування на забезпечення економічного зростання країни.

Застосовується два методи оцінювання якості кредитного портфеля:

3 погляду кредитного ризику, до якого відносять наступні показники: коефіцієнт покриття класифікованих позик; питома вага зважених класифікованих позик; коефіцієнт питомої ваги проблемних позик; коефіцієнт питомої ваги збиткових позик;

3 погляду рівня захищеності від можливих втрат, до якого відносять: коефіцієнт забезпечення позик; коефіцієнт забезпечення збиткових кредитів; коефіцієнт захищеності позик; коефіцієнт покриття позик власним капіталом; ступінь повноти формування резервів за кредитними операціями. 


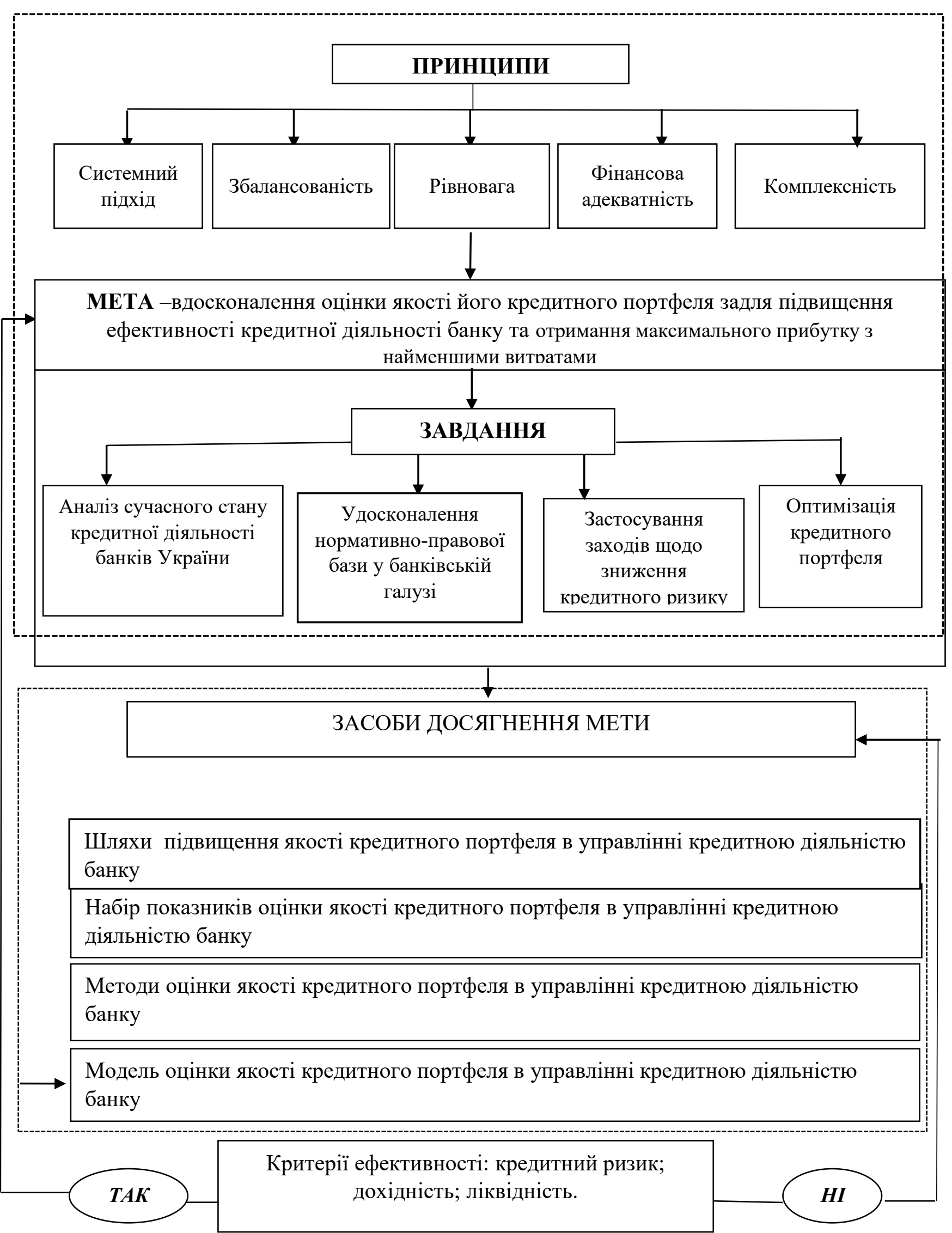

Рисунок 3. Концепція вдосконалення оцінки якості кредитного портфеля в управлінні кредитною діяльністю банку*

*джерело: розроблено авторами 
Основними методами оцінки кредитного ризику є: методи експертних оцінок, статистичні методи, аналітичні методи. Якщо впровадження положень даної концепції в практичну діяльність банку забезпечить ефективної кредитної діяльності банку, то можна зробити висновок, що мета концепції досягнута.

На нашу думку, при побудові концепції вдосконалення оцінки якості кредитного портфеля в управлінні кредитною діяльністю банку варто врахувати ряд факторів (рис.4), які безпосередньо впливають на можливість забезпечення необхідного рівня якості кредитного портфеля.

Фактори, які впливають на рівень якості кредитного портфеля

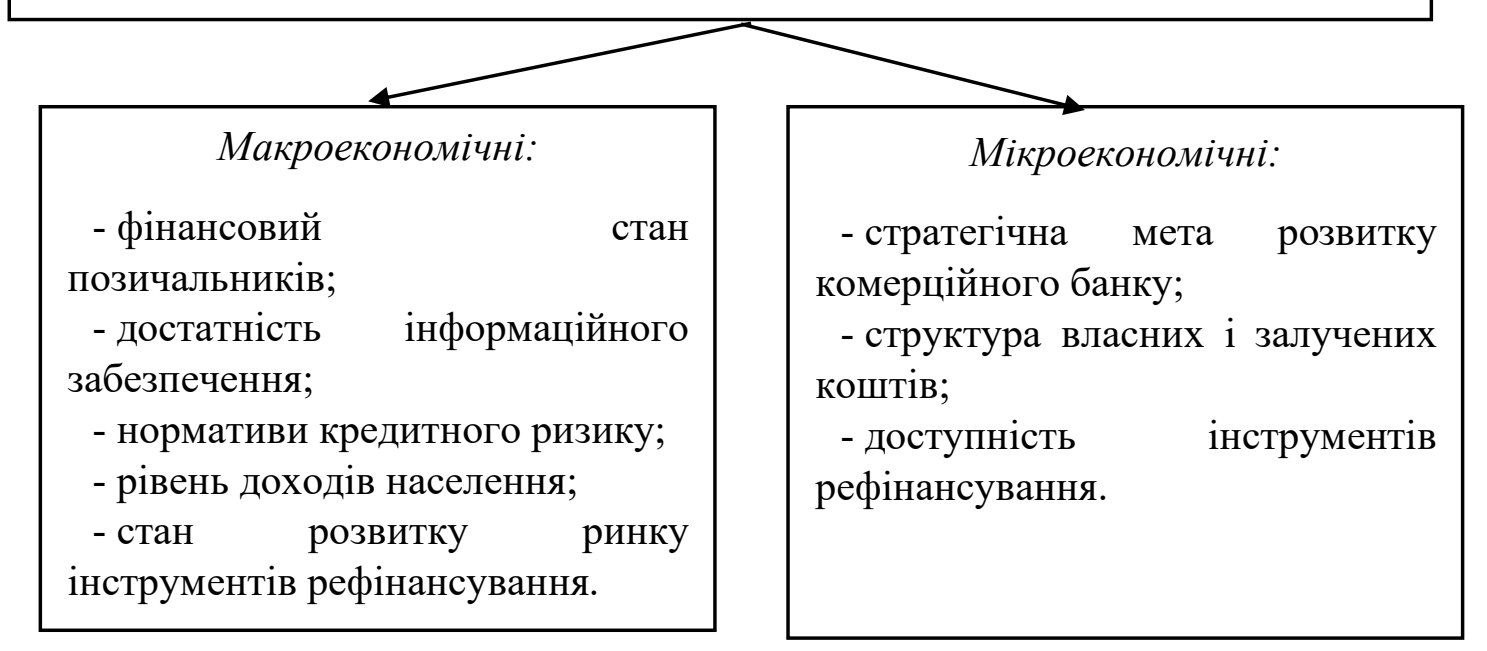

Рисунок 4. Фактори, які впливають на рівень якості кредитного портфеля*

*джерело: розроблено авторами

Варто зазначити, що забезпечення належного рівня ефективності кредитної діяльності банку відбувається протягом восьми етапів, які включають ряд аналітичних процесів 3 метою формування оптимальної структури, виявлення можливих ризиків та невідповідностей, що виникають або можуть виникати під час діяльності та потребують нагального вирішення (рис.5) [7]:

1. Аналіз кредитної діяльності банку в попередньому періоді, який має на меті визначення динаміки обсягу, складу та рівня ефективності цієї діяльності, а саме, аналізують: загальний обсяг кредитного обігу; обіг та рівень використання кредитного потенціалу; структуру кредитного обігу за окремими формами та видами кредиту; питому вагу неповернених кредитів; середній рівень процентних ставок загалом та в тому числі за формами та видами кредиту тощо. Даний етап передбачає аналіз попереднього періоду, тобто, граничного перед нововведенням, що дає змогу зафіксувати фактичні показники для проведення порівняльного аналізу для минулих та планових результатів.

2. Даний етап передбачає дослідження факторів зовнішнього кредитного середовища та прогнозування розвитку, що має на меті визначення впливу форм державного регулювання економічного стану країни тощо.

3. Даний етап передбачає оцінку внутрішнього ресурсного потенціалу банку та можливість його розвитку, а саме: розмір статутного капіталу банку та можливість його нарощення; рівень прогресивності інноваційних технологій у галузі кредитного менеджменту; ефективність діючої структури та методів управління кредитної діяльності. 
4. Даний етап передбачає формування системи стратегічних цілей кредитної діяльності. Вони повинні бути узгоджені зі стратегічними цілями банку, мати альтернативний характер та визначати основні напрями стратегії у галузі кредитування.

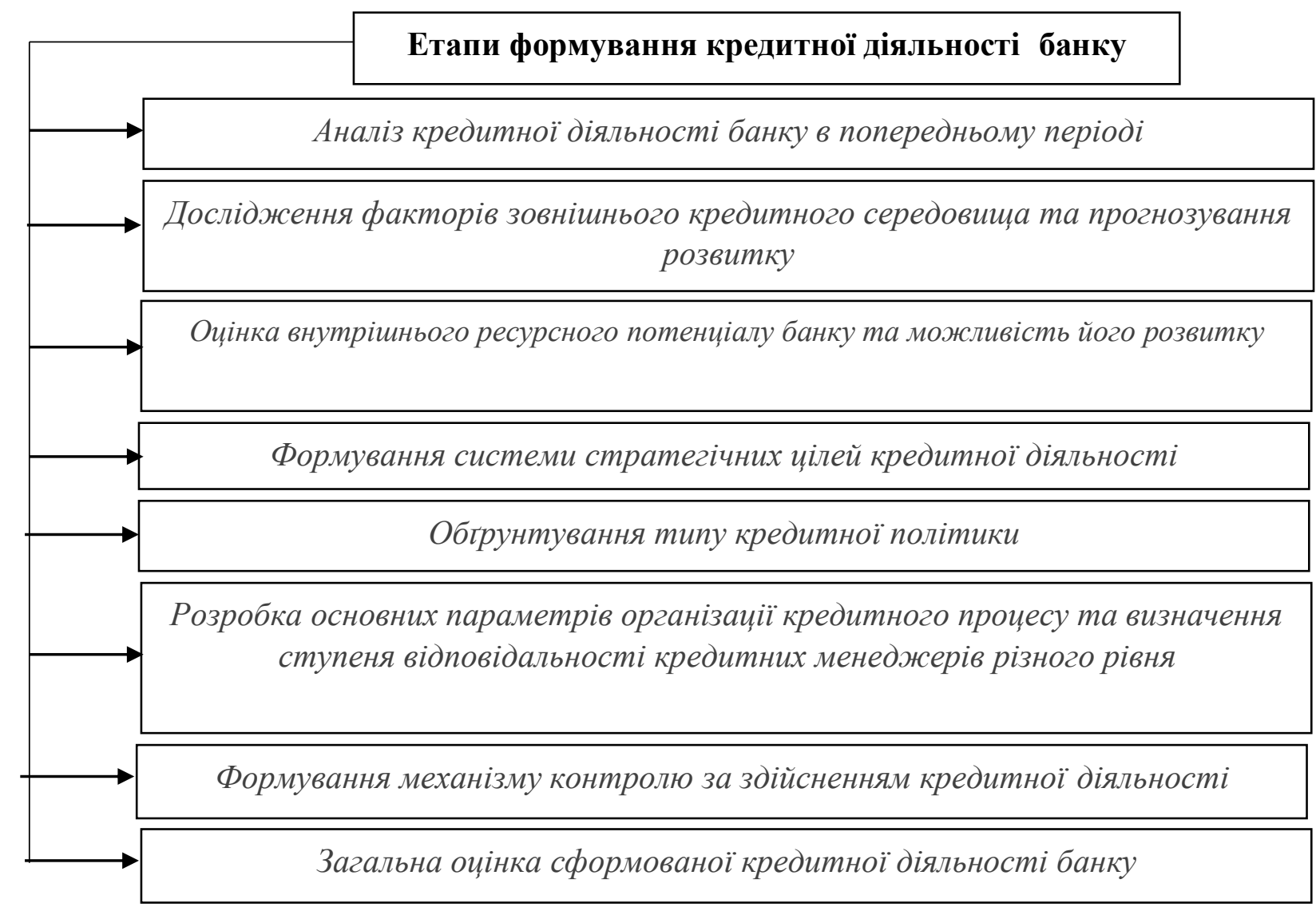

Рисунок 5. Етапи формування кредитної діяльності банку

Джерело: розроблено авторами

5. Даний етап передбачає обгрунтування типу кредитної політики як складової кредитної діяльності. Критерієм такого обгрунтування виступає рівень ризику цих операцій, які будуть здійснюватися у процесі кредитування.

6. Даний етап передбачає розробку основних параметрів організації кредитного процесу та визначення ступеня відповідальності кредитних менеджерів різного рівня. Цей етап має на меті визначення алгоритмів дій щодо прийняття відповідних управлінських рішень за кредитами, що стосується встановлення конкретних вимог, а саме: до прийняття на розгляд кредитної заявки від клієнта; до перевірки окремих даних, наведених у кредитній заявці; до процедури інкасації дебіторської заборгованості за наданими кредитами.

7. Даний етап передбачає формування механізму контролю за здійсненням кредитної діяльності, що має на меті розробку системи заходів щодо пї реалізації в певному періоді.

8. Даний етап передбачає загальну оцінку сформованої кредитної діяльності банку. Вона включає: внутрішню збалансованість цільових показників за окремими напрямами кредитної діяльності банку; допустимість рівня ризиків, економічний ефект, пов'язаний із реалізацією кредитної діяльності тощо. 
На нашу думку, необхідність розробки концепції удосконалення оцінки якості кредитного портфеля в управлінні кредитною діяльністю банку в сучасних умовах викликана:

збільшенням ризиків при кредитуванні;

необхідністю повного та якісного задоволення потреб реального сектору економіки та населення в кредитних засобах;

недостатнім рівнем інформаційного забезпечення процесу управління кредитним портфелем банку та його якістю в умовах мінливого економічного середовища.

Отже, врахування виділених етапів формування кредитної діяльності дозволить банківській установі реалізувати концепцію вдосконалення оцінки якості кредитного портфеля в управлінні кредитною діяльністю банку повною мірою.

Висновки і перспективи подальших досліджень. Банківська система являється необхідним стратегічним сегментом сучасної ринкової економіки будь-якої країни та чинить вплив на економічні та соціальні процеси в країні. Дуже суттєво на економічні процеси в державі впливає діяльність кредитних організацій, основу якої складає саме здійснення банківських операцій. Запропонована концепція вдосконалення оцінки якості кредитного портфеля в управлінні кредитною діяльністю банку дасть змогу адаптуватись до викликів сьогодення та досягти цільових орієнтирів його розвитку. Перспективи подальших досліджень будуть спрямовані на практичну реалізацію концепції вдосконалення оцінки якості кредитного портфеля в управлінні кредитною діяльністю банку.

\section{СПИСОК ВИКОРИСТАНИХ ДЖЕРЕЛ}

1. Волкова Н.І., Кункель А.О. Тенденції та особливості кредитної діяльності вітчизняних банків на сучасному етапі розвитку економіки. Економіка $i$ організація управління, 2018. № 29. С. 52-63.

2. Довгань Ж. Особливості управління кредитною діяльністю банківських установ у сучасних умовах. Свiт фінансів, 2015. № 4. С.43-55.

3. Жукова Н.К., Зражевська Н.В. Сучасний стан та проблеми управління кредитним портфелем комерційних банків. Економічний часопис-XXI, 2013. № 1-2 (1). С.70-72.

4. Степаненко К.Р. Особливості формування кредитного портфеля банку. Науковий вісник Ужгородського національного університету, 2016. № 7. С. 111-114.

5. Офіційний сайт Національного банку України. URL: bank.gov.ua (дата звернення 14.01.21).

6. Макроекономічні показники. [Електронний pecypc]. URL: https://nabu.ua/ru/makroekonomichni-pokazniki.html?com_blog_pager_limit=50 (дата звернення 14.11.20).

7. Вовчак О. Д., Рущишин Н.М., Андрейків Т.Я. Кредит і банківська справа: підручник. К.: Знання, 2008. 361 с.

\section{REFERENCES}

1. Volkova N.I., Kunkelj A.O. (2018). Tendenciji ta osoblyvosti kredytnoji dijaljnosti vitchyznjanykh bankiv na suchasnomu etapi rozvytku ekonomiky. Ekonomika i orghanizacija upravlinnja. 29, 52-63.

2. Dovghanj Zh. (2015). Osoblyvosti upravlinnja kredytnoju dijaljnistju bankivsjkykh ustanov u suchasnykh umovakh. Svit finansiv, 4, 43-55. 
3. Zhukova N.K., Zrazhevsjka N.V. (2013). Suchasnyj stan ta problemy upravlinnja kredytnym portfelem komercijnykh bankiv. Ekonomichnyj chasopys-XXI, 1-2 (1), 70-72.

4. Stepanenko K.R. (2016). Osoblyvosti formuvannja kredytnogho portfelja banku. Naukovyj visnyk Uzhghorodsjkogho nacionaljnogho universytetu, 7, 111-114.

5. Ofitsiinyi sait Natsionalnoho banku Ukrainy. URL: bank.gov.ua. (data zvernennya 14.01.21).

6. Makroekonomichni pokaznyky. URL: https://nabu.ua/ru/makroekonomichnipokazniki.html?com_blog_pager_limit=50 (data zvernennya 15.11.20).

7. Vovchak O. D., Rushhyshyn N.M., Andrejkiv T.Ja. (2008). Kredyt i bankivsjka sprava: pidruchnyk. K.: Znannja, 361.

Волкова В.В., кандидат экономических наук, доцент, доцент кафедры финансов и банковского дела, Донецкий национальный университет имени Васыля Стуса

Волкова Н.И., кандидат экономических наук, доцент, доцент кафедры финансов и банковского дела,Донецкий национальный университет имени Васыля Стуса

Ставская К.А., магистрант, Донецкий национальный университет имени Васыля Стуса

\section{КОНЦЕПЦИЯ СОВЕРШЕНСТВОВАНИЯ ОЦЕНКИ КАЧЕСТВА КРЕДИТНОГО ПОРТФЕЛЯ В УПРАВЛЕНИИ КРЕДИТНОЙ ДЕЯТЕЛЬНОСТЬЮ БАНКА}

В статье определено качество кредитного портфеля как благоприятное состояние его структуры, при котором банк будет иметь возможность обеспечить максимальную доходность при минимальном уровне кредитного риска и оптимальной ликвидности баланса банка. Исследована динамика неработающих активов и выделень банки с наибольшей их долей в кредитном портфеле. Обоснована необходимость более эфррективного управления кредитными рисками и иелесообразность оценки качества кредитного портфеля банка. Разработана конщепция совершенствования оценки качества кредитного портфеля в управлении кредитной деятельностью банка, реализация которой позволит повысить эффективность его деятельности и будет способствовать развитию банковской системь страны. В статье сделан акцент на том, что концепция совериенствования оценки качества кредитного портфеля в управлении кредитной деятельностью банка - целостная система теоретико-методологических взглядов на сущность, иели, задачи и принципь оценки качества кредитного портфеля в управлении кредитной деятельностью банка, а также система организационно-практических подходов к формированию механизма ее реализачии в конкретных условиях. Выделены факторы, влияющие на уровень качества кредитного портфеля. Обосновань этапь формирования кредитной деятельности банка, что позволит банку реализовать концепџиию совершенствования оченки качества кредитного портфеля в управлении его кредитной деятельностью в полной мере.

Ключевые слова: банк, кредитная деятельность, концепция, неработающие кредиты, управление кредитныли рисками, оченка качества кредитного портфеля. 
V.Volkova, PhD in Economics, Associate Professor, Associate Professor of the Department of Finance and Banking, Vasyl Stus Donetsk National University

N.Volkova, PhD in Economics, Associate Professor, Associate Professor of the Department of Finance and Banking, Vasyl Stus Donetsk National University

K.Stavska, undergraduate, Vasyl` Stus Donetsk National University

\section{CONCEPT OF IMPROVING THE CREDIT PORTFOLIO QUALITY ASSESSMENT IN THE BANK'S CREDIT ACTIVITY MANAGEMENT}

The article defines the quality of the loan portfolio as a favorable state of its structure, in which the banking institution will be able to ensure maximum profitability with a minimum level of credit risk and optimal liquidity of the bank's balance sheet. The dynamics of non-performing assets was studied and the banks with the largest share in the loan portfolio were identified. The necessity of more effective credit risk management and the expediency of assessing the quality of the bank's loan portfolio are substantiated. The concept of improving the assessment of the quality of the loan portfolio in the management of the bank's credit activities has been developed, the implementation of which will increase the efficiency of its activities and contribute to the development of the country's banking system.

The article emphasizes that the concept of improving the quality of the loan portfolio in the management of credit activities of the bank - a holistic system of theoretical and methodological views on the nature, purpose, objectives and principles of assessing the quality of the loan portfolio in the management of credit activities, as well as organizational and practical approaches to the formation of the mechanism of its implementation in specific conditions. Factors that affect the level of quality of the loan portfolio are identified. Substantiation of the stages of formation of the bank's lending activity, which will allow the banking institution to implement the concept of improving the assessment of the quality of the loan portfolio in the management of the bank's lending activities in full.

Keywords: bank, credit activity, concept, non - performing loans, credit risk management, credit portfolio quality assessment. 